\title{
PRIORITIES IN THE RISK ASSESSMENT AND RISK MANAGEMENT DURING THE SHIP ACCIDENT AT SEA

\author{
PRIORYTETY W OCENIE RYZYKA I ZARZADZANIU \\ RYZYKIEM W CZASIE KATASTROFY STATKU NA MORZU
}

\author{
Mirosław Gerigk \\ Politechnika Gdańska
}

\begin{abstract}
Summary: The paper concerns the safety of seaborne transportation and is devoted to safety of ocean engineering objects and ships in damaged conditions at sea. A method (procedure) of safety assessment of damaged objects (ships) is presented. The method is oriented on the object performance and risk assessment. For the risk assessment the risk based techniques are applied including the Formal Safety Assessment FSA introduced by IMO. The method (procedure) is based on application of the holistic approach to safety. An influence of factors affecting safety following from the different sources (design, operation, management, human factor) is taken into account. The holistic risk model is implemented which enables to estimate the risk of not surviving a collision (grounding, stranding, terrorist attack, etc.) using the object (ship) performance assessment during the accident. The event tree analysis ETA is used for the risk assessment. The different scenarios of accident are used and they include the hazards, intermediate events, additional events and consequences. The risk estimation is based on the matrix risk model. The safety measure in the method (procedure) is the level of risk. The risk assessment (RA, QRA) is conducted using the risk acceptance criteria (RAC) in the form of either the risk matrix or ALARP concept. The risk assessment is associated with using the risk control options (RCO) as well. Within the method safety is the objective. The procedure of risk management is presented in the paper. Finally, some remarks regarding the prioritization in the risk assessment and risk management during the ship accident at sea are described.
\end{abstract}

Keywords: safety of seaborne transportation, safety management, risk assessment, risk, ocean engineering object in damaged conditions, ship in damaged conditions.

Streszczenie: $W$ artykule przedstawiono metodę oceny bezpieczeństwa statku $w$ stanie uszkodzonym, która oparta jest na ocenie zachowania się statku uszkodzonego oraz na ocenie ryzyka wypadku. Do oceny ryzyka stosuje się analize ryzyka, w tym elementy Formalnej Oceny Bezpieczeństwa FSA. Proponowana metoda oparta jest na zastosowaniu całościowego podejścia do bezpieczeństwa statków. Uwzględnia sie $w$ nim wplyw na bezpieczeństwo czynników o charakterze projektowym, operacyjnym oraz tych, zwiąanych z zarzadzaniem $i$ wpływem czynnika ludzkiego. Zastosowano całościowy model ryzyka, który umożliwia wyznaczenie ryzyka utraty statku, w oparciu o ocene jego zachowania się $w$ czasie wypadku. Analize ryzyka przeprowadza się w oparciu o drzewa zdarzeń ETA. Poszczególne sekwencje zdarzeń moga zwierać zagrożenia, zdarzenia pośrednie, zdarzenia dodatkowe i zdarzenia końcowe. Ryzyko wypadku dla danego scenariusza wypadku oblicza się w oparciu o macierzowy model ryzyka. Miara bezpieczeństwa obiektu $w$ proponowanej metodzie jest ryzyko lub jego poziom. Ocenę ryzyka (RA, QRA) przeprowadza się stosując kryteria akceptacji ryzyka (RAC). W metodzie można zastosować jedno z dwóch kryteriów: macierz ryzyka lub koncepcje ALARP. W ocenie ryzyka i zarzadzajac ryzykiem stosuje się tak zwane opcje kontroli ryzyka (RCO). W artykule przedstawiono procedurę zarządzania bezpieczeństwem.

Stowa kluczowe: bezpieczeństwo transportu morskiego, zarządzanie bezpieczeństwem, ocena ryzyka, ryzyko wypadku, obiekt oceanotechniczny w stanie uszkodzonym, statek $w$ stanie uszkodzonym 
Priorities in the risk assessment and risk management during the ship accident... Priorytety w ocenie ryzyka i zarzadzaniu ryzykiem w czasie katastrofy statku na morzu

\section{Wprowadzenie}

Morza i oceany świata eksploatowane są z uwagi na żywność, zasoby mineralne i energię, co wymaga stałego rozwoju transportu morskiego a w szczególności statków. Akweny te odgrywają coraz ważniejszą rolę z uwagi na rozwój turystyki. Nie należy też zapominać o tym, że nadal obowiązuje zasada strategiczna, że kto rządzi na morzu rządzi lądami.

Statki i obiekty oceanotechniczne powinny charakteryzować się odpowiednimi cechami funkcjonalnymi, efektywnościowymi i tymi, związanymi $\mathrm{z}$ bezpieczeństwem. Dotyczy to $[1,2,3]$ :

- platform i obiektów produkcyjnych: TPG 3300, Spar Truss, TLP - 1 Leg, Buoy, Octobuoy, Semi-submersible, Tower, Spar Classic, TLP - 3 Leg, TLP - 4 Leg, FPSO, SSP buoy;

- wszystkich typów statków, w tym zbiornikowców, chemikaliowców, jednostek OSV (Offshore Supply Vassels), holowników, itd.;

- systemów i obiektów produkcyjnych posadowionych na dnie;

- pływających i stacjonarnych turbin wiatrowych i elektrowni falowych.

Tematyka artykułu ukierunkowana jest na bezpieczeństwo statków w stanie uszkodzonym w czasie katastrofy na morzu a w szczególności zbiornikowców. Jak poważne mogą być konsekwencje katastrof związanych z eksploatacją statków i obiektów oceanotechnicznych, można zorientować się analizując katastrofy, które miały miejsce na świecie w okresie ostatnich kilku dekad. Za najgroźniejsze w XX i XXI wieku można uznać następujące katastrofy [2, 4]:

- katastrofa zbiornikowca Amoco Cadiz (1978) - do morza dostało się ok. 223000 ton ropy;

- katastrofa platformy wiertniczej Piper Alfa (1988) - zginęło 167 osób, straty 3.4 miliarda dolarów;

- katastrofa zbiornikowca Exxon Valdez (1989) - plama ropy na powierzchni $1300 \mathrm{~km}^{2}$, zginęły niezliczone ilości ryb, ptaków, fok, morsów i wielorybów;

- wojna w Zatoce Perskiej (1991) - uwolniono, wg. różnych źródeł, od 800 tys. do $1,5 \mathrm{mln}$ ton ropy naftowej do morza; rozlewy ropy pokryły też $49 \mathrm{~km}^{2}$ powierzchni lądu a $953 \mathrm{~km}^{2}$ zostały skażone;

- katastrofa platformy wydobywczej Deepwater Horizon (2010) - 11 pracowników poniosło śmierć, 17 osób zostało rannych, największa katastrofa ekologiczna w historii USA, całkowita ilość wycieku ropy do morza to prawie 5 mln baryłek (czyli ponad 666 tysięcy ton) ropy.

Jeśli chodzi o największe w historii katastrofy zbiornikowców można je sklasyfikować w sposób następujący:

- Atlantic Empress (1979) - 287000 ton;

- Casillia de Bellver (1983) - 252000 ton; 
- Exxon Valdez (1989) - 37000 ton;

- Khark V (1989) - 80000 ton;

- ABT Summer (1991) - 260000 ton;

- Erika (1999) - 20000 ton;

- Prestige (2002) - 63000 ton.

$\mathrm{Z}$ analizy powyższych i innych katastrof na morzu wynika, że dotychczasowe wypadki nie uchroniły ludzkości przed popełnianiem często tych samych błędów. Bardzo pouczająca w tym względzie jest także analiza wypadków, które wydarzyły się na akwenie Morza Bałtyckiego [5, 6].

\section{Statek lub obiekt oceanotechniczny w stanie uszkodzonym}

Statek lub obiekt oceanotechniczny znajduje się w stanie uszkodzonym, jeśli na skutek wystąpienia takich zagrożeń jak kolizja, uderzenie o przeszkodę, wejście na mieliznę, atak terrorystyczny czy inne, nastąpi dostawanie się dużych ilości wody zaburtowej do wnętrza kadłuba statku lub obiektu, co spowoduje znaczne obniżenie poziomu bezpieczeństwa do jego utraty włącznie. Statek (obiekt) może znaleźć się w stanie uszkodzonym także wtedy, gdy uszkodzeniu ulega jeden z podstawowych podsystemów statku (obiektu) lub gdy doszło na przykład do ataku terrorystycznego, co może prowadzić do dużych zmian w zachowaniu się statku (obiektu) [2].

Proces zatapiania przedziału lub danej grupy przedziałów wodoszczelnych, kadłuba statku lub obiektu uszkodzonego, dzieli się na etapy i fazy. Wyróżnia się etapy: początkowy, etapy pośrednie i końcowy. Fazy zatapiania związane są ze stopniem wypełnienia zatapianego przedziału wodą zaburtową. Należy zdawać sobie sprawę z faktu, że w czasie zatapiania woda zaburtowa może dostawać się do wnętrza przedziału jaki i wydostawać się z niego. Proces ten zależy od wielu czynników. Na statek lub obiekt w stanie uszkodzonym działają różne wymuszenia wewnętrzne i zewnętrzne, najczęściej o charakterze losowym. W stanie uszkodzonym, statek (obiekt) powinien zachować zarówno stateczność jak i pływalność. Przy czym za ważniejszą należy uznać zdolność statku (obiektu) do zachowania stateczności. Obie cechy decydują o przetrwaniu procesu zatapiania przez statek (obiekt) na każdym etapie i w każdej fazie jego zatapiania.

Powyższe cechy w znacznym stopniu decydują o tym, czy po zakończeniu procesu zatapiania, statek (obiekt) uszkodzony może kontynuować misję, czy należy go przeholować do portu (o własnych siłach, na holu), czy też statek (obiekt) powinien oczekiwać na pomoc z zewnątrz. Może też dojść do utraty statku (obiektu) na skutek utraty stateczności i/lub utraty pływalności [2]. 
Priorities in the risk assessment and risk management during the ship accident... Priorytety w ocenie ryzyka i zarzadzaniu ryzykiem w czasie katastrofy statku na morzu

\section{Metoda oceny bezpieczeństwa obiektu (statku) w stanie uszkodzonym}

Ocenę bezpieczeństwa statków (obiektów oceanotechnicznych) w stanie uszkodzonym można przeprowadzić za pomocą metod prawno-nakazowych (preskrypcyjnych), które oparte są na obowiązujących przepisach lub za pomocą metod, opartych na ocenie zachowania się statku (obiektu) i ocenie ryzyka wypadku [2].

Jeśli chodzi o statki, istniejące metody mają charakter preskrypcyjny i oparte są na wymaganiach zawartych w przepisach konwencji (SOLAS, MARPOL). Metody te trudno zastosować do oceny bezpieczeństwa statków w stanie uszkodzonym, przeznaczonych do przewozu produktów ropopochodnych, chemikaliów i gazu. Wynika to między innymi $\mathrm{z}$ faktu, że są one ukierunkowane raczej na projektowanie. Niektóre elementy tych metod mają charakter semiprobabilistyczny lub wręcz deterministyczny. Najpoważniejszym mankamentem tych metod jest to, że przy ich zastosowaniu bierze się pod uwagę ograniczoną liczbę scenariuszy wypadku. Właśnie to wyklucza możliwość ich zastosowania do oceny bezpieczeństwa obiektu w stanie uszkodzonym w czasie katastrofy [2,7].

Jeśli chodzi o morski przemysł wydobywczy, to uczyniono $\mathrm{w}$ ostatnich kilku dekadach znacznie większy postęp, jeśli chodzi o zastosowanie metod oceny bezpieczeństwa obiektów oceanotechnicznych opartych na ocenie ryzyka. Zdecydowano się między innymi na zastosowanie do oceny bezpieczeństwa metodyki opartej na Przypadku Bezpieczeństwa (ang. Safety Case) - przypadek Piper Alfa. Zdaniem autora, przemysł ten nadal boryka się z brakiem poprawnego modelu/modeli ryzyka wypadku, nieprzetrwania katastrofy [2].

Do oceny bezpieczeństwa statków w stanie uszkodzonym należy zastosować metodę opartą na ocenie zachowania się statku i ocenie ryzyka wypadku. Strukturę takiej metody przedstawiono na rysunku 1 [2].

Główną cechą metody jest to, że do oceny bezpieczeństwa statku zastosowano tak zwane podejście całościowe, które polega na [2]:

- uwzględnieniu wpływu na bezpieczeństwo statku czynników o charakterze projektowym, eksploatacyjnym $i$ tych związanych $\mathrm{z}$ zarządzaniem i czynnikiem ludzkim;

- zastosowaniu całościowego modelu ryzyka, który umożliwia wzięcie pod uwagę możliwie największej liczby scenariuszy wypadku.

Do oceny zachowania się statku można wykorzystać badania na modelach fizycznych lub symulację komputerową. Ocena zachowania się statku uszkodzonego dotyczy oceny jego pływalności, stateczności i zachowania się pod wpływem wymuszeń wewnętrznych (zatapianie, przesunięcie ładunku) 
i zewnętrznych (oddziaływanie falowania, wiatru). Zachowanie się statku uszkodzonego za pomocą symulacji komputerowej można określić przy użyciu układu równań różniczkowych stochastycznych w dziedzinie czasu.

$\mathrm{Na}$ obecnym etapie badań wykorzystuje się też model liniowy zachowania sie statku w stanie uszkodzonym, który oparty jest na obliczeniach $\mathrm{w}$ dziedzinie częstości falowania.

Siły hydrodynamiczne działające na kołyszący się statek uszkodzony wraz z siłami od działania wody w zatopionym przedziale można wyznaczyć za pomocą hybrydowej metody, która zawiera między innymi elementy metody panelowej wyznaczania sił ciśnienia w wodzie.

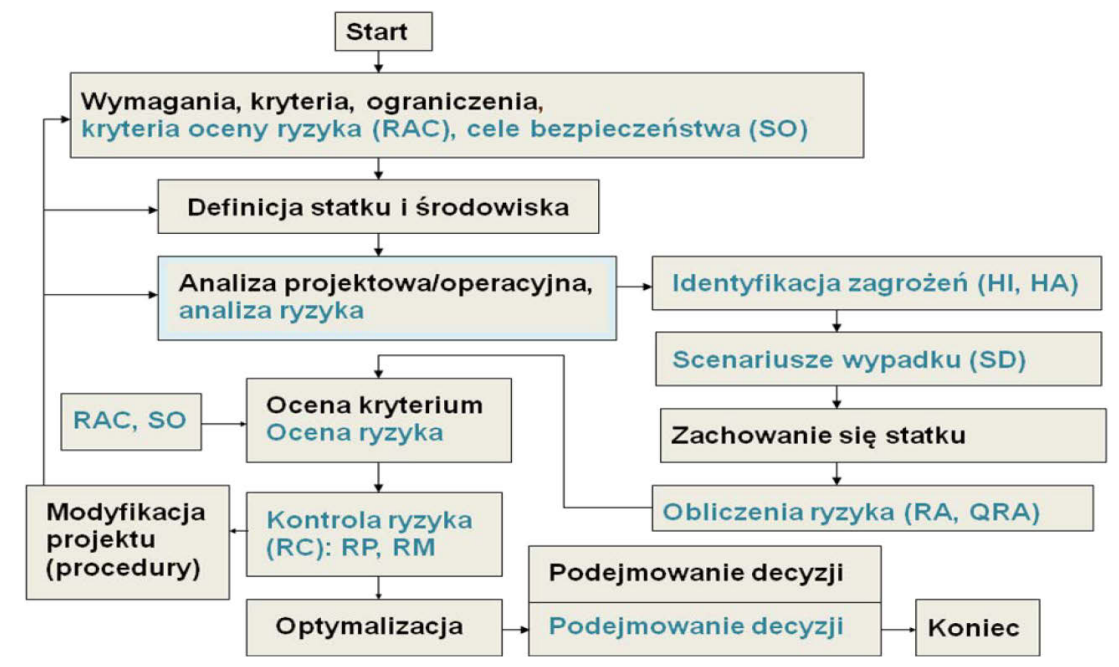

Rys. 1 Struktura metody oceny bezpieczeństwa obiektów (statków) w stanie uszkodzonym, opartej na ocenie zachowania się obiektu (statku) i ocenie ryzyka.

Ocena zachowania się statku na wszystkich etapach i we wszystkich fazach jego zatapiania, wymaga znajomości przebiegów czasowych kołysań liniowych i kątowych, dla wybranych stopni swobody statku przedstawionych schematycznie na rysunku 2. 
Priorities in the risk assessment and risk management during the ship accident... Priorytety w ocenie ryzyka i zarzadzaniu ryzykiem w czasie katastrofy statku na morzu

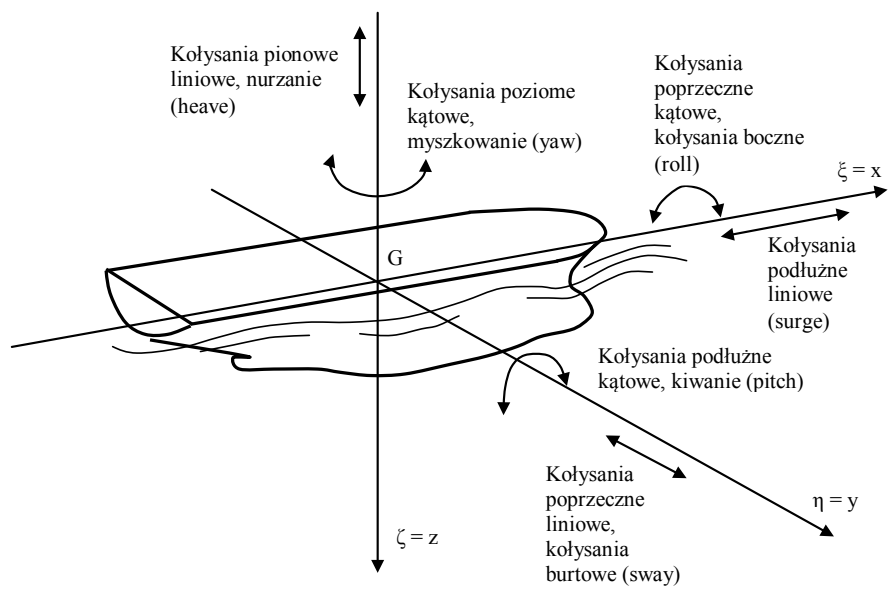

Rys. 2 Stopnie swobody obiektu (statku) na swobodnej powierzchni wody sfalowanej.

W przypadku statku w stanie uszkodzonym, podstawową charakterystyką używaną do oceny jego zachowania się, jest przebieg czasowy kołysań bocznych kątowych statku (roll). Przykład takiego przebiegu przedstawiono na rysunku 3 [2].

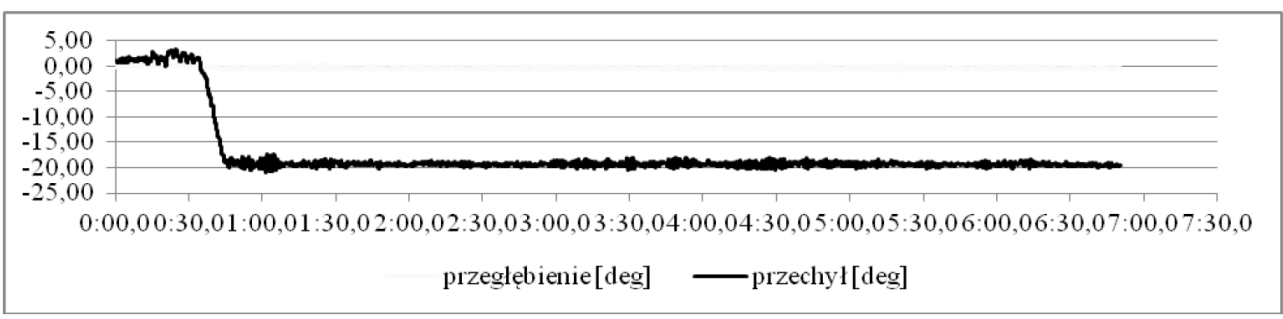

Rys. 3 Przyktad przebiegu czasowego kotysań bocznych kątowych statku (roll).

Ocena zachowania się statku $\mathrm{w}$ stanie uszkodzonym umożliwia opracowanie scenariuszy wypadku w postaci drzew zdarzeń ETA. Drzewa te umożliwiają przeprowadzenie szacowanie ryzyka wypadku dla poszczególnych scenariuszy wypadku [2]. Ocena ryzyka wypadku, które w metodzie nazwano ryzykiem nieprzetrwania katastrofy przez statek polega na oszacowaniu wartości ryzyka, co przedstawiono w kolejnym rozdziale. Następnie dokonuje się oceny ryzyka (RA, QRA) stosując kryteria akceptacji ryzyka (RAC) w postaci macierzy ryzyka lub koncepcji ALARP. Przy ocenie ryzyka i zarządzając ryzykiem stosuje się tak zwane opcje kontroli ryzyka (RCO) $[2,8,9]$. 


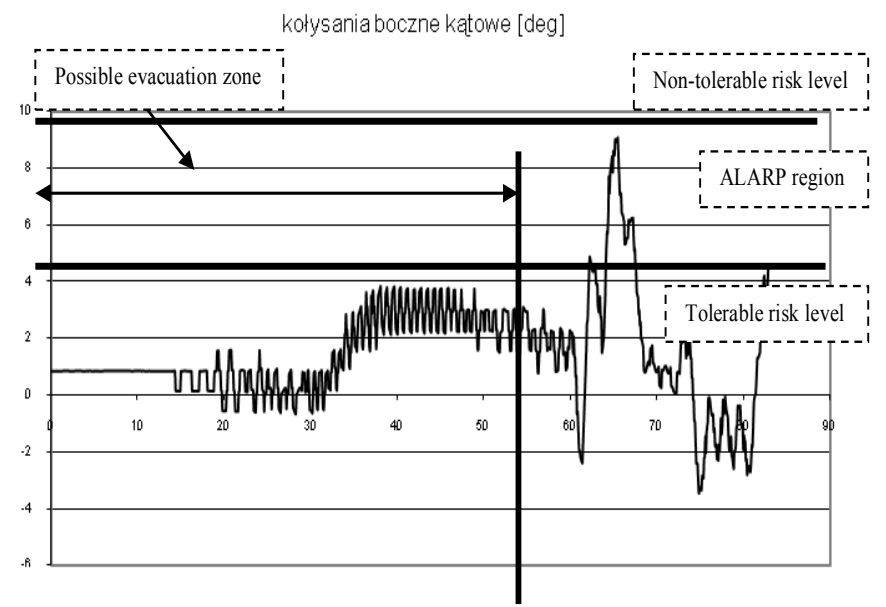

Rys. 4 Przykład zastosowania koncepcji ALARP do oceny czasu ewakuacji statku w stanie uszkodzonym w oparciu o przebieg kołysań bocznych kątowych statku (roll).

Przykład zastosowania koncepcji ALARP do oceny czasu ewakuacji załogi i pasażerów ze statku, wykorzystując przebieg procesu kołysań bocznych statku w stanie uszkodzonym, przedstawiono na rysunku 4. Miarą bezpieczeństwa statku w stanie uszkodzonym w proponowanej metodzie jest poziom ryzyka [2].

\section{Ryzyko nieprzetrwania katastrofy przez statek (obiekt)}

Ryzyko wypadku w metodzie zostało zdefiniowane jako iloczyn prawdopodobieństwa wystąpienia danego zagrożenia $\mathrm{P}_{\mathrm{i}} \mathrm{i}$ konsekwencji wypadku $\mathrm{C}_{\mathrm{i}}[2,10]$ :

$$
\mathrm{R}_{\mathrm{i}}=\mathrm{P}_{\mathrm{i}} \mathrm{C}_{\mathrm{i}}
$$

$\mathrm{Z}$ kolei ryzyko nieprzetrwania kolizji przez statek zostało wyznaczone modelując ryzyko w metodzie za pomoca macierzowego modelu ryzyka. Bez względu na metodę zastosowaną do analizy $\mathrm{i}$ oceny zachowania się statku $\mathrm{w}$ stanie uszkodzonym (badania na modelu fizycznym czy symulacja komputerowa), ryzyko nieprzetrwania kolizji przez statek należy obliczyć w sposób następujący [2, 9]:

$$
\mathrm{R}=\mathrm{P}_{\mathrm{C}} \mathrm{P}_{\mathrm{F} / \mathrm{C}} \mathrm{PoC} \mathrm{C}_{\mathrm{C}}
$$

gdzie: $\mathrm{P}_{\mathrm{C}}$ - prawdopodobieństwo wystąpienia kolizji, $\mathrm{P}_{\mathrm{F} / \mathrm{C}}$ - prawdopodobieństwo zatapiania obiektu po wystąpieniu kolizji, PoC - prawdopodobieństwo nieprzetrwania katastrofy przez statek, $\mathrm{C}_{\mathrm{C}}$ - konsekwencje katastrofy szacowane na podstawie analizy zachowania się uszkodzonego statku.

Obliczając ryzyko nieprzetrwania katastrofy, należy obliczyć prawdopodobieństwa warunkowe, dotyczące zdarzeń inicjujących $\mathrm{ZI}_{\mathrm{i}}$, zdarzeń głównych $\mathrm{ZG}_{\mathrm{j}}$ (zagrożenia), zdarzeń pośrednich $\mathrm{ZP}_{\mathrm{k}}$ i zdarzeń końcowych $\mathrm{ZK}_{1}$ (konsekwencje w scenariuszu wypadku). Przy czym prawdopodobieństwa zdarzeń końcowych $\mathrm{ZK}_{\mathrm{l}}$, rozumiane jako prawdopodobieństwo nieprzetrwania katastrofy przez statek, można wyznaczyć za pomocą jednej z czterech metod [2,11]: zero-jedynkowej, statycznej, metody opartej o definicję prawdopodobieństwa zupełnego przetrwania 
Priorities in the risk assessment and risk management during the ship accident... Priorytety w ocenie ryzyka i zarzadzaniu ryzykiem w czasie katastrofy statku na morzu

kolizji przez statek A lub metody opartej na ocenie zachowania się statku w stanie uszkodzonym i identyfikacji charakterystyk procesu stochastycznego kołysań bocznych statku w stanie uszkodzonym (metoda własna).

W przypadku, gdy w danym scenariuszu zdarzeń, na etapie zdarzeń pośrednich, występują też zdarzenia dodatkowe $Z_{\mathrm{j}}$, wyznaczenie prawdopodobieństwa warunkowego wystąpienia konsekwencji $C_{i}$ (zdarzeń końcowych) $\operatorname{PoC}\left(\mathrm{C}_{\mathrm{i}}\right)$ znacznie się komplikuje [2,11]. Stopień komplikacji związanych z oceną ryzyka nieprzetrwania katastrofy przez statek, przy uwzględnieniu wpływu czynnika ludzkiego, środowiska i zarządzania (podejście całościowe do bezpieczeństwa), przedstawiono schematycznie na rysunku 5.

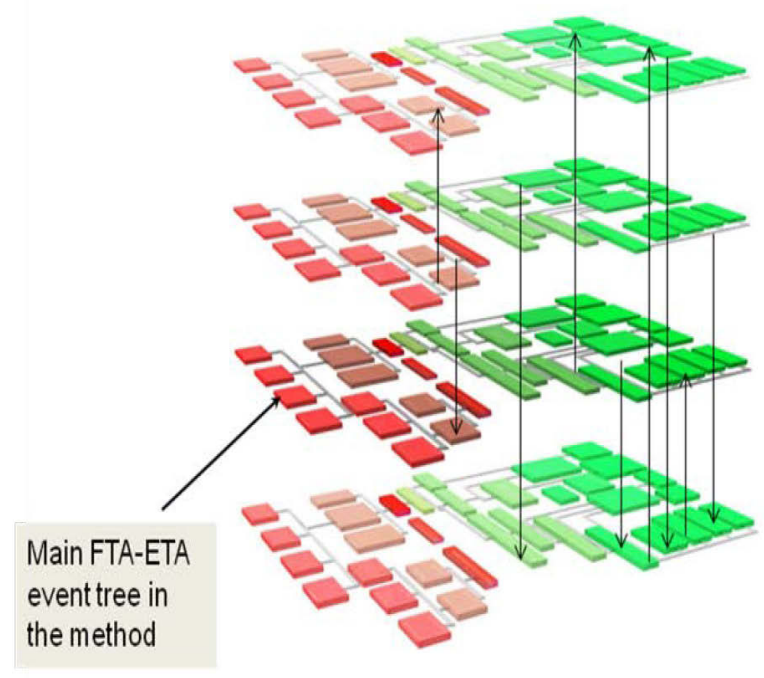

$$
\begin{aligned}
& \text { Human-level } H F / C \\
& R=P_{C} P_{F / C} P_{O C C} C_{H F / C} \\
& \text { Environment-level E/C } \\
& R=P_{C} P_{F / C} P_{O C C} C_{E / C} \\
& \text { Ship - level CS/C } \\
& R=P_{C} P_{F / C} P_{C C C} / C \\
& \text { Finacial-level EURO/C } \\
& R=P_{C} P_{F / C} P_{O C C} C_{E U R O C}
\end{aligned}
$$

Rys. 5 Schemat przedstawiajacy wplyw czynnika ludzkiego, środowiska i zarzadzania (podejście całościowe do bezpieczeństwa) na ocenę ryzyka nieprzetrwania katastrofy przez statek: $R=P_{C} P_{F / C}$ PoC $C_{C S / C}[2]$.

\section{Procedura zarządzania bezpieczeństwem statku (obiektu)}

System zarządzania bezpieczeństwem obiektu w stanie uszkodzonym oparty jest na uwzględnieniu wpływu na bezpieczeństwo czynników bezpieczeństwa, ocenie ryzyka wypadku i zarządzaniu ryzykiem [2]. Zarządzanie ryzykiem można zdefiniować jako systematyczny i całościowy proces, który umożliwia ilościową ocenę ryzyka i zarządzanie nim. Zarządzanie ryzykiem w metodzie polega na ocenie ryzyka (RAC) i zarządzaniu nim, poprzez monitorowanie i kontrolowanie (RCO, podejmowanie decyzji dotyczących bezpieczeństwa obiektu), w oparciu o zdefiniowany system bezpieczeństwa statku (czynniki bezpieczeństwa) [2]. $\mathrm{Z}$ technicznego punktu widzenia, zarządzanie ryzykiem w metodzie jest oparte na strategii redukcji ryzyka, która polega ogólnie na redukcji prawdopodobieństwa wystąpienia danych zdarzeń i redukcji konsekwencji wypadku. Zarządzanie bezpieczeństwem statku $\mathrm{w}$ stanie uszkodzonym $\mathrm{w}$ metodzie oparte jest na schemacie przedstawionym na rysunku 6 . 


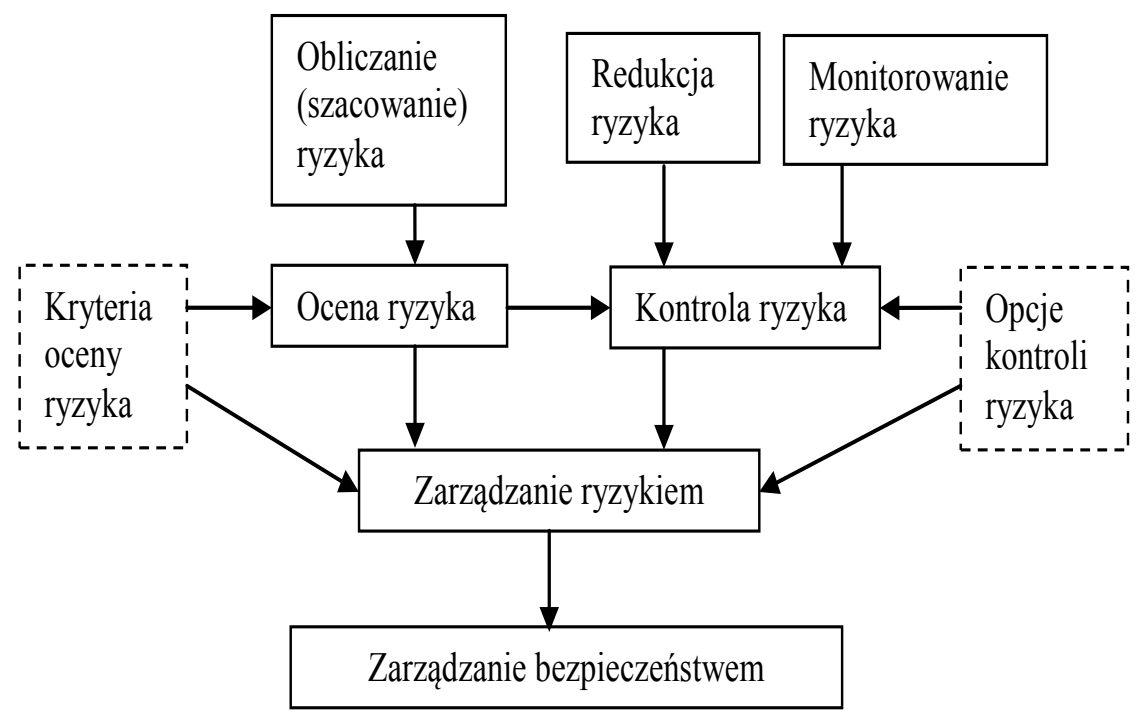

Rys. 6 Schemat zarzq̨dzania bezpieczeństwem statku w stanie uszkodzonym w omawianej metodzie.

Dynamika sytuacji w czasie katastrofy statku na morzu, wymaga szybkiego podejmowania decyzji, dotyczących bezpieczeństwa statku, z ukierunkowaniem na bezpieczeństwo ludzi, mienia i środowiska naturalnego. Szybkie podejmowanie decyzji wymaga zastosowania systemu oceny bezpieczeństwa statku $\mathrm{w}$ stanie uszkodzonym. Schemat takiego systemu przedstawiono na rysunku 7 [2].

\section{Priorytety w ocenie ryzyka i zarządzaniu ryzykiem $w$ czasie katastrofy statku na morzu}

Proponuje się wprowadzenie priorytetów w ocenie ryzyka i zarządzania ryzykiem w czasie katastrofy na morzu.

Procedura wprowadzania priorytetów ma postać następującą:

- najpierw należy oszacować ryzyko uszkodzenia statku;

- następnie należy ocenić ryzyko na podstawie ustalonych kryteriów oceny ryzyka (koncepcja ALARP);

- statki dla których ryzyko uszkodzenia przekracza poziom ryzyka tolerowanego, w koncepcji ALARP, powinny podlegać stałej kontroli, zgodnie ze schematem zarządzania bezpieczeństwem statku $\mathrm{W}$ stanie uszkodzonym, przedstawionym na rysunku 6 .

Zarządzanie ryzykiem w metodzie zarządzania bezpieczeństwem statku jest oparte na strategii redukcji ryzyka, która polega na [2]: 
1. redukcji prawdopodobieństwa wystąpienia danych zdarzeń, obejmującej:

- redukcję prawdopodobieństwa wystąpienia zdarzeń pośrednich $\mathrm{ZP}_{\mathrm{k}}$;

- redukcję prawdopodobieństwa wystąpienia zdarzeń dodatkowych $\mathrm{ZD}_{\mathrm{j}}$;

2. redukcji konsekwencji wypadku, obejmującej:

- redukcję prawdopodobieństwa wystąpienia zdarzeń końcowych $\mathrm{ZK}_{1}, \mathrm{w}$ przypadku, różnie $\mathrm{w}$ zależności od tego czy występują zdarzenia dodatkowe czy też nie.

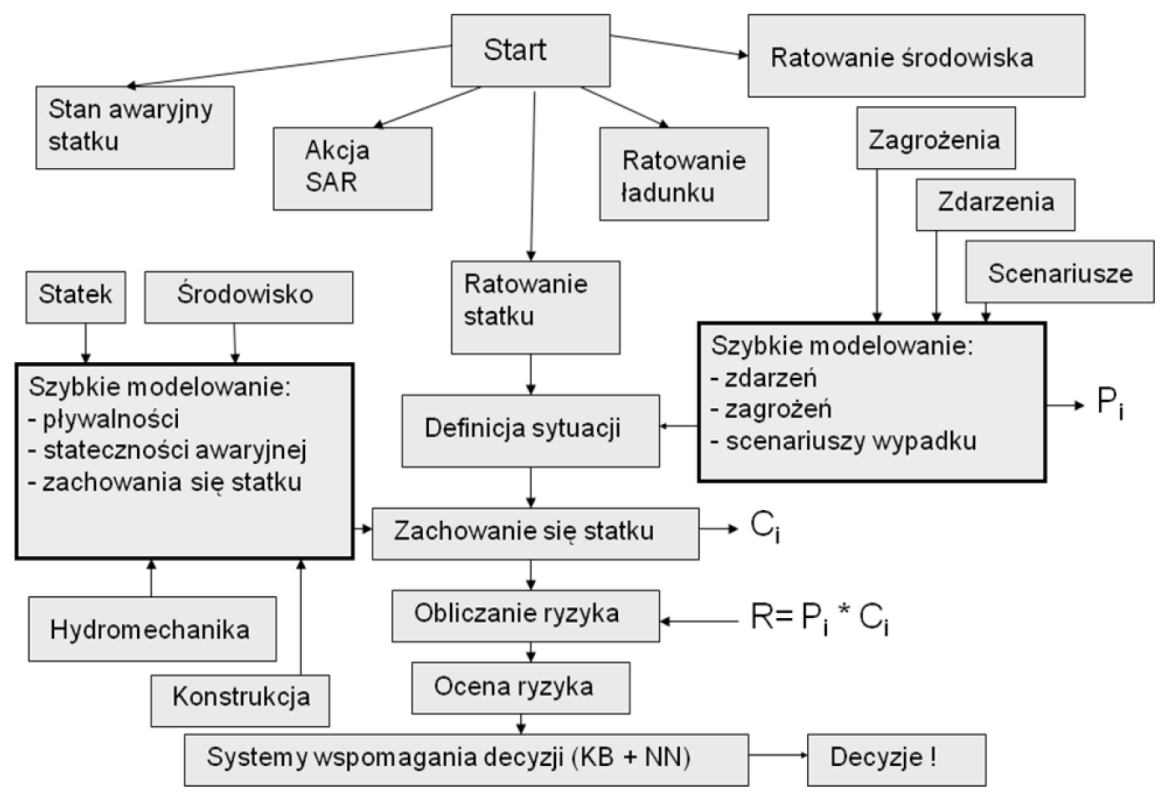

Rys. 7 System oceny bezpieczeństwa statku w stanie uszkodzonym w czasie katastrofy.

W związku z powyższym proponuje się wprowadzenie środków redukcji ryzyka takich, jak: zmiana trasy statku, obowiązkowa asysta holowników, inne... . Proponuje sie także wprowadzenie oznaczenia "High Attention Vessel" dla statków, w przypadku których ryzyko uszkodzenia statku jest zbyt wysokie.

Proponuje się wprowadzenie pojęcia ryzyka rozlewu zdefiniowanego w sposób następujący [12]:

$$
\mathrm{R}=\mathrm{P}_{\text {DRIFT }} \mathrm{P}_{\text {GROUNDING } / \text { DRIFT }} \mathrm{S}_{\text {SPILL SIZE }} \mathrm{I}_{\text {SPILL IMPACT }}
$$

gdzie: $\mathrm{P}_{\text {DRIFT }}$ - prawdopodobieństwo, że statek ulegnie uszkodzeniu i będzie dryfował; $\mathrm{P}_{\text {GROUNDING / DRIFT }}$ - prawdopodobieństwo warunkowe, że statek wejdzie na mieliznę (uderzy o przeszkodę), na skutek tego, że uległ uszkodzeniu i dryfował; S SPILL sIzE - konsekwencje wielkości rozlewu; I IPILL IMPACT konsekwencje rozlewu na środowisko (uciążliwość rozlewu). 


\section{Wnioski końcowe}

Obecne prace badawcze związane są z dalszym rozwojem omówionej metody. Rozbudowywany jest całościowy model ryzyka oraz procedura zarządzania ryzykiem wypadku. Zamierzonym efektem badań jest opracowanie modelu obliczeniowego do szybkiej symulacji sytuacji na morzu w czasie katastrofy, który powinien umożliwiać ocenę zachowania się obiektu (statku) w stanie uszkodzonym i ocenę ryzyka na kolejnych etapach katastrofy.

Przedstawione wyniki badań są ściśle związane z poprzednimi pracami autora oraz realizacją projektu badawczego własnego p.t. „Opracowanie modelu do analizy i oceny zachowania się statku w czasie katastrofy z wykorzystaniem modelu ryzyka nieprzetrwania kolizji przez statek", finansowanego przez Ministerstwo Nauki i Szkolnictwa Wyższego (decyzja $\mathrm{Nr}$ 5703/B/T02/2010/39). Projekt ten jest realizowany na Politechnice Gdańskiej w latach 2010-2012, pod kierunkiem autora.

\section{Bibliografia}

[1] Faltinsen O.M.: Sea loads on ships and offshore structures. Cambridge University Press, Cambridge 1990.

[2] Gerigk M.: Kompleksowa metoda oceny bezpieczeństwa statku w stanie uszkodzonym $\mathrm{z}$ uwzględnieniem analizy ryzyka. Monografie 101, Wydawnictwo Politechniki Gdańskiej, Gdańsk 2010.

[3] Moan T.: Marine structures for the future. Centre for Offshore Research and Engineering, National University of Singapore, CORE Report No. 2003-01, Singapore 2003.

[4] http://pl.wikipedia.org/wiki/Kategoria:Katastrofy_morskie.

[5] Romanowski Cz., Witek Piotr.: Może być strasznie. Budownictwo Okrętowe, nr 3 (548), Marzec 2005, pp. 27-31.

[6] Romanowski Cz., Stareńczak P.B.: Co z tym Bałtykiem? Nasze Morze, nr 12 (24), grudzień 2007.

[7] IMO: Resolution MSC.194(80) Annex 2, Adoption of Amendments to the International Convention for the Safety of Life at Sea, 1974, As Amended, adopted on 20.05.2005.

[8] Jasionowski A., Vassalos D.: Conceptualising Risk. Proceedings of the 9th International Conference on Stability of Ships and Ocean Vehicles STAB 2006, Rio de Janeiro, 25-29 September 2006.

[9] Skjong R., Vanem E., Rusas S., Olufsen O.: Holistic and Risk Based Approach to Collision Damage Stability of Passenger Ships. Proceedings of the $9^{\text {th }}$ International Conference on Stability of Ships and Ocean Vehicles STAB 2006, Rio de Janeiro, 25-29 September 2006.

[10] Pillay A., Wang J.: Technology and Safety of Marine Systems. Elsevier Ocean Engineering Book Series, Volume 7, Elsevier 2003. 
Priorities in the risk assessment and risk management during the ship accident... Priorytety w ocenie ryzyka i zarzadzaniu ryzykiem w czasie katastrofy statku na morzu

[11] Borysiewicz M., Furtek A., Potempski S.: Poradnik metod ocen ryzyka związanego z niebezpiecznymi instalacjami procesowymi. Instytut Energii Atomowej, Otwock - Świerk 2000.

[12] Eide M.S.: Risk Based Ship Prioritisation, Reducing risk thorough intelligent ship monitoring. DNV Research \& Innovation, Brest, 19 October 2006.

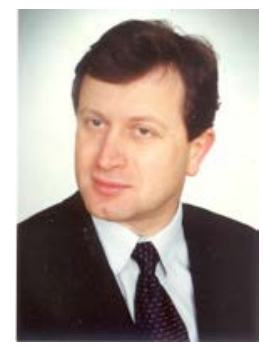

Dr. hab. ini. Miroslaw Gerigk, adiunkt $w$ Katedrze Teorii i Projektowania Okrętów na Wydziale Oceanotechniki i Okrętownictwa Politechniki Gdańskiej. Specjalizacja: hydromechanik, bezpieczeństwo statków $i$ transportu morskiego, bezpieczeństwo statków w stanie uszkodzonym. 